\title{
Pengaruh Penggunaan Model Pembelajaran Kooperatif Tipe Team Game Tournament (TGT) Berbantuan Media Kokami Terhadap Hasil Belajar Siswa
}

\author{
Firman $^{1 *}$, Nurmiati ${ }^{1}$, Nurfitrayani $^{1}$ \\ 1. Pendidikan Biologi, Fakultas Keguruan dan Ilmu Pendidikan, Universitas Sulawesi Barat \\ *email: firman@unsulbar.ac.id
}

\begin{abstract}
Abstrak
Penelitian ini merupakan penelitian eksperimen semu yang bertujuan untuk mengetahui pengaruh penerapan metode pembelajaran kooperatif tipe Team Game Tournament (TGT) berbantuan media Kotak Kartu Misterius (Kokami). Penelitian dilaksanakan di SMA Negeri 1 Alu dengan sampel 27 siswa Kelas XI MIA1 sebagai kelompok eksperimen dan 25 siswa kelas XI MIA2 sebagai kelompok kontrol. Data dikumpulkan melalui evaluasi hasil belajar yang dilaksanakan pada akhir pembelajaran menggunakan instrument berupa 30 butir soal pilihan ganda. Temuan penelitian ini adalah adanya perbedaan hasil belajar kelas eksperimen dengan kelas kontrol. Hasil analisis data menunjukkan nilai Sig. $0,000<0,05$ yang berarti bahwa terdapat pengaruh penerapan model pembelajaran kooperatif tipe TGT berbantuan media kokami terhadap hasil belajar.
\end{abstract}

Kata Kunci : TGT, Kokami, Hasil Belajar

\section{PENDAHULUAN}

Hasil belajar merupakan pernyataan mengenai pencapaian siswa yang diukur pada akhir sebuah proses pembelajaran. Pencapaian ini mencakup apa yang harus diketahui, apa yang dapat dilakukan, dan apa yang dipahami oleh peserta didik terkait pembelajaran yang telah dilaluinya. Tinggi atau rendahnya hasil belajar merupakan indikator kualitas pembelajaran sekaligus sebagai pedoman dalam mengarahkan pembelajaran selanjutnya.

Pencapaian hasil belajar peserta didik yang maksimal dapat dilakukan melalui berbagai cara, salah satunya adalah melalui pemilihan model pembelajaran yang sesuai. Sintaks suatu model pembelajaran merupakan sebuah skenario yang dirancang dan diatur sedemikian rupa untuk memunculkan aktivitas fisik maupun mental peserta didik yang bertujuan untuk mendukung penguasaan kompetensi yang dituntut dalam sebuah proses pembelajaran.

Pembelajaran kooperatif tipe Team Game Tournament (TGT) merupakan salah satu model pembelajaran yang menurut banyak penelitian sangat mendukung pencapaian kompetensi peserta didik. TGT yang dikembangkan oleh Slavin, merupakan model pembelajaran yang menggabungkan kerja kelompok dengan turnamen dan dapat digunakan untuk meningkatkan pemahaman mengenai konsep dan kemampuan berkomunikasi. Dalam pembelajaran ini peserta didik dapat memainkan gim akademik dengan tim lainnya untuk mengumpulkan poin yang akan berkontribusi terhadap skor kelompok (Veloo, Md-Ali, \& Chairany, 2016)

Menurut Slavin, (2009) langkah-langkah pembelajaran kooperatif tipe TGT meliputi presentasi kelas, berlajar kelompok (tim), game, turnamen, dan rekognisi tim. Model 
pembelajaran ini sangat cocok untuk mengajar tujuan pembelajaran yang dirumuskan dengan tajam (Ningtiyas \& Siswaya, 2012) sehingga menghasilkan prestasi belajar siswa yang lebih baik (Putra, 2015) serta meningkatkan kemampuan penalaran peserta didik (Purnamasari, 2014).

Game atau permainan menjadi komponen penting dari pembelajaran TGT. Selain sebagai ice breaking, permainan juga menjadi media penyampaian materi pembelajaran yang menyenangkan bagi peserta didik. Beberapa penelitian melaporkan bahwa integrasi media pembelajaran tertentu seperti media puzzle (Yudiasmini, Agung, \& Ujianti, 2014), kartu soal (Hidayanto, 2014), dan teka-teki (Fajri \& Martini, 2012) ke dalam pembelajaran kooperatif tipe TGT mampu mendukung pembelajaran dan pencapaian hasil belajar yang maksimal.

Media lain yang dinilai memiliki efek menguntungkan jika diintegrasikan dalam pembelajaran kooperatif tipe TGT adalah kotak dan kartu misterius (Kokami). Penggunaan media ini dapat meningkatkan hasil belajar (Rusiana, 2014), meningkatkan motivasi belajar serta berpengaruh terhadap kemampuan berfikir kritis siswa (Marga, Isnaini, \& Utami, 2018).

Kokami merupakan media pembelajaran berbentuk kotak yang di dalamnya terdapat beberapa kartu misterius (Rahmawati \& Kurniawan, 2017). Kartu tersebut memuat pesan, perintah, gambar, pertanyaan, sanksi, atau tugas lain yang harus dikerjakan siswa (Rusiana, 2014). Penggunaan media Kokami dapat menanamkan pengetahuan dan menarik perhatian siswa (Putri, Prihandono, \& Putra, 2017)

Berdasarkan uraian di atas, kita dapat melihat bahwa model pembelajaran kooperatif tipe TGT dan media Kokami mampu mendukung pembelajaran. Melalui penelitian ini akan diselidiki bagaimana pengaruh penggunaan model pembelajaran kooperatif tipe TGT berbantuan media Kokami terhadap hasil belajar siswa.

\section{Metode}

Penelitian ini merupakan penelitian quasy experiment yang bertujuan untuk mengetahui pengaruh penggunaan model pembelajaran kooperatif tipe TGT berbantuan media Kokami pada hasil belajar peserta didik. Penelitian ini dilaksanakan di SMA Negeri 1 Alu, Kecamatan Tinambung, Kabupaten Polewali Mandar, Sulawesi Barat pada semester ganji tahun ajaran $2019 / 2020$.

Sampel dipilih secara acak dan dibagi ke dalam dua kelompok. Kelompok eksperimen yang terdiri dari 27 siswa kelas XI MIA 1 dan kelompok kontrol yang terdiri dari 25 siswa kelas XI MIA 2. Kelompok eksperimen mendapatkan perlakuan berupa penerapan pembelajaran kooperatif tipe TGT berbantuan media Kokami, sementara kelompok kontrol diajar menggunakan model pembelajaran konvensional.

Data hasil belajar diperoleh melalui pemberian tes hasil belajar yang dilaksanakan pada akhir pembelajaran. Instrument yang digunakan berupa 30 butir soal pilihan ganda. Informasi mengenai ada atau tidak adanya pengaruh pembelajaran kooperatif tipe TGT berbantuan media kokami diperoleh dengan membandingkan hasil belajar kelas eksperimen dengan kelas kontrol. Analisis data dilakukan menggunakan program IBM SPSS Statistics 25. 


\section{Hasil}

Analisis butir soal pada signifikansi 0,05 dengan $r$ tabel sebesar 0,268 dan alfa Cronbach 0,706 menunjukkan terdapat 27 soal valid dan 3 soal tidak valid, serta 29 soal reliabel dan 1 soal tidak reliabel.

Data hasil belajar yang telah diperoleh kemudian dianalisis. Rekap data hasil belajar dapat dilihat pada tabel berikut:

Tabel 1. Perbandingan hasil belajar kelas eksperimen dan kelas control

\begin{tabular}{lll}
\hline Data & Kelas & Kelas \\
& Eksperimen & Kontrol \\
\hline Nilai Tertinggi & 80,00 & 67 \\
Nilai Terendah & 37,00 & 23 \\
Mean & 57,81 & 43,52 \\
Median & 57,00 & 40,00 \\
Modus & 40,00 & 37,00 \\
Simpangan Baku & 13,70 & 13,08 \\
Variansi & 187,77 & 171,26 \\
\hline
\end{tabular}

Selanjutnya dilakukan uji prasyarat berupa uji normalitas dan homogenitas yang hasilnya dapat dilihat pada 59able berikut:

Tabel 2. Hasil uji normalitas

\begin{tabular}{llccc}
\hline \multirow{2}{*}{ Kelas } & \multicolumn{4}{c}{ Shapiro-Wilk } \\
\cline { 2 - 5 } & \multicolumn{2}{c}{ Statistic } & Df & Sig. \\
\hline Kelas Eksperimen & 0,936 & 27 & 0,097 \\
Kelas Kontrol & 0,952 & 25 & 0,277 \\
\hline
\end{tabular}

Tabel 3. Hasil uji homogenitas

\begin{tabular}{cccccc}
\hline $\begin{array}{c}\text { Nilai Hasil } \\
\text { Belajar }\end{array}$ & Levene Statistic & df1 & df2 & Sig. \\
\hline Based on Mean & 0,181 & 1 & 50 & 0,672 \\
\hline
\end{tabular}

Tabel diatas menunjukkan nilai Sig. kelas eksperimen dan kelas kontrol pada Uji ShapiroWilk lebih besar dari 0,05 sehingga disimpulkan bahwa data berdistribusi normal. Demikian juga hasil Uji Levene yang menunjukkan nilai Sig. lebih besar dari 0,05 sehingga disimpulkan bahwa data bersifat homogen.

Setelah uji prasyarat terpenuhi maka dilakukan uji t independen untuk melihat pengaruh pembelajaran kooperatif tipe TGT terhadap hasil belajar siswa SMA Negeri 1 Alu. Hasil uji t dapat dilihat pada table berikut: 
Tabel 4. Hasil uji t independent

\begin{tabular}{lll}
\hline t-test for Equality of Means & & \\
\hline $\mathrm{T}$ & $\mathrm{df}$ & Sig. (2-tailed) \\
3,805 & 50 & 0,000 \\
\hline
\end{tabular}

Tabel di atas menunjukkan nilai Sig. (2-tailed) sebesar 0,000 lebih kecil dari 0,05 yang berarti bahwa pembelajaran kooperatif tipe TGT berbantuan media Kokami memiliki pengaruh yang signifikan terhadap hasil belajar peserta didik SMA Negeri 1 Alu.

\section{Pembahasan}

Hasil penelitian ini menunjukkan adanya perbedaan hasil belajar kelas eksperimen dengan kelas kontrol, dimana mean hasil belajar kelas eksperimen sebesar 57,81, lebih tinggi dari mean hasil belajar kelas kontrol sebesar 43,42. Perbedaan hasil belajar pada kelas yang diajar menggunakan model pembelajaran kooperatif tipe TGT berbantuan media kokami dengan hasil belajar pada kelas yang diajar menggunakan metode konvensional menunjukkan bahwa bahwa pembelajaran kooperatif tipe TGT berbantuan media Kokami memiliki pengaruh terhadap hasil belajar.

Adanya perbedaan hasil belajar antara kelompok eksperimen dan kelompok kontrol tidak lepas dari kemampuan pembelajaran TGT berbantuan media Kokami dalam memunculkan aktifitas-aktifitas peserta didik yang menunjang penguasaan kompetensi yang dituntut dalam pembelajaran. Turnamen yang diadakan selama pembelajaran membuat siswa menjadi lebih kompetitif sehingga mereka terdorong untuk menunjukkan performa yang lebih baik dari teman kelasnya yang lain. Hal ini membuat siswa lebih aktif dan merasa terlibat langsung dalam pembelajaran. Penelitian Carini, Kuh, \& Klein (2006) menyatakan bahwa keterlibatan mahasiswa dalam pembelajaran memiliki hubungan positif dengan hasil belajar dan kemampuan berfikir kritis.

Aspek lain dari pembelajaran kooperatif TGT yang mempengaruhi hasil belajar adalah adanya kemandirian belajar yang ditunjukkan oleh peserta didik. Menurut Purnamasari (2014) peserta didik memiliki kemandirian belajar tinggi jika diajar menggunakan pembelajaran kooperatif tipe TGT. Kemandirian belajar berperan sebagi penunjang dalam mencapai tujuan pembelajaran sehingga siswa mampu belajar dengan baik dan meningkatkan hasil belajarnya (Nurlia dkk., 2017).

Langkah pembelajaran kooperatif TGT yang juga sangat mempengaruhi hasil belajar adalah game dan turnamen. Tahapan ini merupakan fase dimana peserta didik menunjukkan perilaku yang sangat aktif. Beberapa aktivitas yang dapat dilihat misalnya berdiskusi, membaca dan mencari jawaban terkait pertanyaan atau tugas-tugas yang harus mereka laksanakan. Agar game atau permainan dan kompetisi berlangsung dengan baik, maka biasanya digunakan media-media pembelajaran tertentu. Dalam konteks penelitian ini, media pembelajaran yang digunakan adalah kotak kartu misterius (Kokami).

Penggunaan media Kokami sangat membantu terlaksananya pembelajaran yang baik. Kartu-kartu misterius yang disimpan dalam kotak membuat siswa penasaran mengenai isi kartu tersebut. Materi-materi atau pertanyaan-pertanyaan yang tidak terduga, mendorong antusiasme dan memotivasi siswa dalam menjelaskan materi maupun menjawab pertanyaan yang terdapat 
pada kartu. Hal serupa dikemukakan oleh Marga et al., (2018) yang menyatakan bahwa motivasi siswa mengalami peningkatan setelah menggunakan media pembelajaran kokami.

Penerapan pembelajaran kooperatif TGT berbantuan media kokami menciptakan suasana belajar menyenangkan. Siswa bersama-sama mencari informasi terkait materi maupun jawaban pertanyaan-pertanyaan yang ada di kartu untuk kemudian didiskusikan dengan anggota kelompok sendiri dan dipaparkan kepada kelompok lain. Hal ini membantu pserta didik dalam memahami materi yang sedang diajarkan sekaligus melatih kemampuan komunikasinya. Menurut Veloo et al. (2016), pembelajaran kooperatif tipe TGT menggabungkan kerja kelompok dengan turnamen dan dapat digunakan untuk meningkatkan pemahaman mengenai konsep dan kemampuan berkomunikasi.

Selama pembelajaran guru menjadi fasilitator sementara peserta didik secara mandiri mencari tahu hal-hal yang mereka perlukan untuk melaksanakan tugas yang ada di kartu. Mereka membangun pemahaman dengan bertukar fikiran dengan anggota kelompok dan mengaitkan informasi baru dengan skema yang sudah mereka ketahui sebelumnya. Hal ini mendorong terciptanya pembelajaran yang bermakna. Menurut (Huang, Chiu, Liu, \& Chen (2011), pembelajaran bermaknam menekankan pada proses peserta didik dalam mendapatkan informasi baru dan hubungannya dengan pengalaman dan pengetahuan yang sudah dimiliki dalam rangka membentuk pemahaman yang unik dan bersifat personal.

Melalui penerapan pembelajaran kooperatif tipe TGT berbantuan media kokami, dapat dilihat terciptanya pembelajaran menyenangkan, suasana belajar yang aktif, keterlibatan peserta didik secara langsung dalam pembelajaran, serta pembelajaran bermakna yang membuat siswa lebih mudah memahami materi pelajaran. Pemahaman peserta didik mengenai materi pada gilirannya akan mendukung pemenuhan tujuan pembelajaran dan pencapaian hasil belajar yang lebih maksimal.

\section{Kesimpulan}

Hasil penelitian menunjukkan adanya perbedaan hasil belajar peserta didik kelompok eksperimen yang diajar menggunakan model pembelajaran kooperatif tipe TGT berbantuan media kokami dengan peserta didik kelompok kontrol yang diajar menggunakan model pembelajaran konvensional. Mean hasil belajar kelas eksperimen sebesar 57,81, lebih tinggi dari mean hasil belajar kelas kontrol sebesar 43,42. Analisis data menggunakan program IBM SPSS Statistics 25 menunjukkan nilai Sig. 0,00 lebih kecil dari 0,05 sehingga dapat disimpulkan bahwa terdapat pengaruh penerapan model pembelajaran kooperatif team game tournament (TGT) berbantuan media kotak kartu misterius (kokami) terhadap hasil belajar.

\section{Referensi}

Carini, R. M., Kuh, G. D., \& Klein, S. P. (2006). Student engagement and student learning: Testing the linkages. Research in Higher Education. https://doi.org/10.1007/s11162-0058150-9

Fajri, L., \& Martini, K. (2012). Upaya peningkatan proses dan hasil belajar kimia materi koloid melalui pembelajaran kooperatif tipe TGT (Teams Games Tournament) dilengkapi dengan teka-teki. Jurnal Pendidikan Kimia (JPK). 
Hidayanto, E. (2014). PENERAPAN MODEL PEMBELAJARAN KOOPERATIF TIPE TGT ( TEAMS GAMES TOURNAMENTS ) MENGGUNAKAN KARTU SOAL. Jurnal Pendidikan Dan Keguruan.

Huang, Y. M., Chiu, P. S., Liu, T. C., \& Chen, T. S. (2011). The design and implementation of a meaningful learning-based evaluation method for ubiquitous learning. Computers and Education. https://doi.org/10.1016/j.compedu.2011.05.023

Marga, K. M., Isnaini, M., \& Utami, L. S. (2018). PENGARUH MEDIA KOKAMI (KOTAK DAN KARTU MISTERIUS) TERHADAP KETERAMPILAN BERPIKIR KRITIS DAN MOTIVASI BELAJAR SISWA KELAS VIII SMP NEGERI 19 MATARAM TAHUN PELAJARAN 2017/2018. ORBITA: Jurnal Kajian, Inovasi Dan Aplikasi Pendidikan Fisika. https://doi.org/10.31764/orbita.v4i2.573

MIFTAH RAHMAWATI, A., \& Yonisa Kurniawan, R. (2017). ANALISIS HASIL PENGEMBANGAN MEDIA KOKAMI (KOTAK DAN KARTU MISTERIUS) UNTUK MENINGKATKAN KETERAMPILAN BERPIKIR KRITIS, AKTIVITAS BELAJAR DAN KETUNTASAN BELAJAR SMP-SMA. Jurnal Pendidikan Ekonomi (JUPE), 5(3).

Ningtiyas, P., \& Siswaya, H. (2012). PENGGUNAAN METODE KOOPERATIF TIPE TGT DILENGKAPI MODUL DAN LKS DITINJAU DARI AKTIVITAS SISWA. Jurnal Penelitian Pembelajaran Fisika. https://doi.org/10.26877/jp2f.v3i1/april.386

Nurlia, N., Hala, Y., Muchtar, R., Jumadi, O., \& Taiyeb, M. (2017). Hubungan Antara Gaya Belajar, Kemandirian Belajar, dan Minat Belajar dengan Hasil Belajar Biologi Siswa. Jurnal Pendidikan Biologi, 6(2). https://doi.org/10.24114/jpb.v6i2.6552

Purnamasari, Y. (2014). Pengaruh Model Pembelajaran Kooperatif Tipe Teams Games Tournament (Tgt) Terhadap Kemandirian Belajar Dan Peningkatan Kemampuan Penalaran Dan Koneksi Matematik Peserta Didik SMPN 1 Kota Tasikmalaya. Jurnal Pendidikan Dan Keguruan. https://doi.org/10.1097/gme.0b013e318230e286

Putra, F. G. (2015). Eksperimentasi Model Pembelajaran Kooperatif Tipe Teams Games Tournament (TGT) Berbantuan Software Cabri 3D di Tinjau Dari Kemampuan Koneksi Matematis Siswa. Jurnal Pendidikan Matematika.

Putri, AKID. Prihandono, T. Putra, P. (2017). Penerapan Model Pembelajaran Talking Stick Disertai Metode Demonstrasi Berbantuan Media Kokami. JURNAL PEMBELAJARAN FISIKA, 5(4), 321-328. Retrieved from https:/jurnal.unej.ac.id/index.php/JPF/article/view/4226

Rusiana, Y. (2014). PENGGUNAAN MEDIA KOKAMI PADA MATA PELAJARAN IPA UNTUK MENINGKATKAN HASIL BELAJAR SISWA KELAS VA SDN DARUNGAN 01 KECAMATAN TANGGUL KABUPATEN JEMBER. Pancaran.

Slavin, R. E. (2005). Cooperative Learning: Teori, Riset dan Praktik. In International Encyclopedia of Education. https://doi.org/10.1016/B978-0-08-044894-7.00494-2 
Veloo, A., Md-Ali, R., \& Chairany, S. (2016). Using cooperative teams-game-tournament in 11 religious school to improve mathematics understanding and communication. Malaysian Journal of Learning and Instruction. https://doi.org/10.32890/mjli2016.13.2.4

Yudiasmini, N. komang evi, Agung, A. . G., \& Ujianti, P. rahayu. (2014). Penerapan Model Pembelajaran Kooperatif Tipe Teams Games Tournament (Tgt) Berbantuan Media Puzzle Dalam Meningkatkan Perkembangan Kognitif. E-Journal PG-PAUD Universitas Pendidikan Ganesha Jurusan PENDIDIKAN ANAK USIA DINI. 